\title{
Comprehension Abilities of Idioms according to Semantic Types and Familiarity in School-Aged Children with High-Functioning Autism Spectrum Disorder
}

\author{
Song-I Lee ${ }^{a}$, Hee-Sook Bae ${ }^{b}$, Youngmee Lee \\ aDepartment of Speech-Language Therapy E Aural Rehabilitation, Graduate School of Health and Welfare, Woosong University, Daejeon, Korea \\ ${ }^{b}$ Department of Speech-Language Therapy \& Aural Rehabilitation, Woosong University, Daejeon, Korea \\ ${ }^{c}$ Department of Communication Disorders, Tongmyong University, Busan, Korea
}

Correspondence: Youngmee Lee, $\mathrm{PhD}$ Department of Communication Disorders, Tongmyong University, 428 Sinseon-ro, Nam-gu, Busan 48520, Korea

Tel: $+82-51-629-2135$

Fax: +82-51-629-2019

E-mail: ymlee@tu.ac.kr; ymlee3060@gmail.com

Received: April 4, 2016

Revised: May 19, 2016

Accepted: May 28, 2016

This work is based on the master's thesis of the first author.

\begin{abstract}
Objectives: The purposes of this study were to investigate the differences in comprehension between children with high-functioning autism spectrum disorder (HFA) and children with typical development (TD) by type of idiom (emotion/action expression) and familiarity (high/low) and to investigate the proportion of misunderstood idioms (literal interpretation, idiom quote) within each group. Methods: Fifteen children with HFA and 15 agematched children with TD were included in this study. An idiom comprehension task was developed for the study, which consisted of 40 items ( 10 emotion-familiar idioms, 10 emotion-unfamiliar idioms, 10 action-familiar idioms, and 10 action-unfamiliar idioms). Results: The idiom comprehension accuracy of children with HFA was significantly lower than children with TD. Children with HFA showed significantly lower accuracy than children with TD in comprehending emotion idioms. Both children with HFA and children with TD had significantly higher accuracy in familiar idioms than in unfamiliar idioms. For children with HFA, there was no significant difference in the proportion of misunderstanding between literal interpretation of idioms and idiom quote. Conclusion: Children with HFA showed lower accuracy in idiom comprehension than children with TD. Children with HFA had more difficulties in comprehending emotion idioms and unfamiliar idioms than children with TD. These results suggest that the type and familiarity of idioms should be considered in teaching idioms to children with HFA in speech-language therapy.
\end{abstract}

Keywords: High-functioning autism spectrum disorder, School-aged children, Idioms, Semantic type, Familiarity 자폐스펙트럼장애(autism spectrum disorder)는 사회성 결핍, 의 사소통에서의 어려움, 반복행동, 특정 부분에 대한 지나친 관심 등 의 특징을 보이며, 경우에 따라서는 인지발달 지체가 동반되기도 한다(American Psychiatric Association, 2000). Wing (1981)은 자 폐스펙트럼장애를 동작성 지능 기준으로 70 이상은 고기능(highfunctioning), 70 미만은 저기능(low-functioning)으로 분류하였 다. 고기능 자폐스펙트럼장애 아동은 표준화된 어휘 검사에서 정 상 범주의 수행을 보이더라도 화용론적 측면에서 결함을 나타낸
다. 이들은 영유아기에 제한된 의사소통 기능을 보이다가 학령기에 는 감정과 관련된 어휘나 문구를 이해하고 사용함에 있어 어려움 을 보인다(Kasari, Chamberlain, \& Bauminger, 2001; Reed, 2012; Taylor \& Harris, 1995). 선행 연구에서는 고기능 자폐스펙트럼장 애 아동이 사실적인 단어에만 집중하여 정서적인 단서를 찾아내지 못하고 상대방의 발화 의도를 추론하는 데에 종종 실패한다고 보 고되고 있다(Gold, Faust, \& Goldstein, 2010; Lee, 2007; Oh, Hwang, \& Lim, 2013; Paul, Orlovski, Marcinko, \& Volkmar, 2009; Vogin- 
droukas \& Zikopoulou, 2011; Vulchanova, Talcott, Vulchanov, Stankova, \& Eshuis, 2012).

상대방과 대화를 유지하면서 의사소통하기 위해서는 상대방의 말을 듣고 의도를 이해하는 화용론적 능력이 필요한데, 이러한 화 용론적 능력은 의미 추론, 비유 언어 등의 능력과 관련이 있다(Levorato \& Cacciari, 1995; Nippold, 1998; Owens, 1991; Paul et al., 2009). 비유 언어는 일반적으로 은유(metaphor), 직유(simile), 관용 어(idiom), 속담(proverb) 등으로 구성된다(Moran, Nippold, \& Gillon, 2006). 이중에서도 관용어는 둘 이상의 어휘소가 결합되어 구 성 요소의 의미가 아닌 제 3 의 단일 의미를 가지는 특징이 있고(Lee, 1996), 관용어 학습이 부족할 때 의사소통, 사회적 참여, 학업성취 등에서 문제가 발생한다고 보고되고 있다(Hyun, Kim, \& Lim, 2011; Olswang, Coggins, \& Svensson, 2007). 이와 같이 관용어가 전반적 인 의사소통에서 중요한 부분이기 때문에 초등학교 입학 후에 관용 어 학습이 정규교과과정에 포함이 되고, 이후 고등학교까지 교육되 고 있다(Ahn, 2006; Han, 2004). 관용어 사용 능력은 학령기를 관통 하여 청소년기와 성인기를 거쳐 꾸준히 발달하며 학교에서 관용어 학습이 본격적으로 이루어지는 것도 초등학교 고학년에 이르러서 다. 그러나 관용어 이해 및 사용 능력이 7세부터 꾸준히 발달한다고 주장한 Vogindroukas와 Zikopoulou (2011)의 연구가 있고, 이보다 좀 더 빠른 시기인 5-7세부터 관용어 이해 능력이 발달하기 시작한 다는 주장도 있다(Hyun et al., 2011). 이러한 선행 연구에 비취볼 때 초등학교 저학년 아동의 관용어 이해 능력을 살펴보는 것은 이후의 관용어 학습이나 관용어 사용 능력의 발달적 척도가 될 수 있다.

학령기 관용어 이해가 또래와의 사회적 관계와 학습적인 측면에 서 중요하다고 보고되면서 최근에는 일반 아동뿐 아니라, 자폐스 펙트럼장애, 단순언어장애, 읽기이해부진, 주의력결핍과잉행동장 애 아동 등 다양한 대상으로도 관용어 이해에 대한 연구가 늘고 있 다(Ahn, 2006; Han, 2004; Hyun et al., 2011; Lee, Ko, \& Hwang, 2014; Olswang et al., 2007). Vogindroukas와 Zikopoulou (2011)는 고기능 자폐스펙트럼장애와 아스퍼거증후군으로 진단받은 학령 기 아동과 일반 아동, 일반 성인을 대상으로 관용어 이해 과제를 실 시하였다. 그 결과, 고기능 자폐스펙트럼장애와 아스퍼거증후군 아 동의 관용어 이해 과제 점수가 일반 아동과 성인에 비해서 낮았으 며, 관용어를 문자 의미 그대로 해석하는 오류를 빈번히 보였다. Whyte, Nelson과 Scherf (2014)는 5-12세의 자폐스펙트럼장애 아 동과 일반 아동의 관용어, 문법, 마음이론을 평가하였다. 그 결과, 자폐스펙트럼장애 아동의 관용어 이해 능력이 생활연령을 일치시 킨 일반 아동에 비해서는 낮았으나 문법 능력을 일치시킨 일반 아 동과는 비슷한 수행력을 보였으며, 자폐스펙트럼장애 아동의 관용
어 이해 점수는 마음이론과 상관이 높은 것으로 나타났다. Lee 등 (2015)의 연구도 6-11세의 고기능 자폐스펙트럼장애 아동의 관용 어 이해 능력이 일반 아동에 비해서 낮았다고 보고하였다. 선행 연 구에서는 고기능 자폐스펙트럼장애 아동이 일반 아동에 비해 학 습과 일상 대화에 필요한 관용어의 이해에 어려움을 보였다고 일관 되게 언급하고 있다. Lee 등(2014)은 초등학교 2, 3학년에 재학 중인 아스퍼거증후군 아동과 일반 아동을 대상으로 관용어의 의미 분 류(감정표현 관용어, 행위표현 관용어)에 따른 관용어 이해 능력에 차이가 있는지 살펴보았다. 그 결과, 감정표현 관용어에서는 아스퍼 거증후군 아동이 일반 아동에 비해서 유의하게 낮은 점수를 보였 으나 행위표현 관용어에서는 두 집단 간에 유의한 점수 차이가 나 타나지 않았다.

Nippold와 Taylor (2002)는 관용어의 친숙도가 11세 일반 아동 과 16 세의 일반 청소년의 관용어 이해 능력에 영향을 미치는지 살 펴보았다. 아동은 친숙도에 따라서 관용어 이해 능력에 유의한 차 이를 보였으나, 청소년은 친숙도에 따른 관용어 이해 능력에 유의한 차이가 없었다. 즉, 관용어의 친숙도는 대상자의 언어 경험에 따라 서 영향을 받는다고 할 수 있다(Nippold \& Taylor, 1995). Oh와 Lee (2014)는 경도 지적장애 성인과 언어연령을 일치시킨 아동을 대상 으로 관용어의 친숙도에 따른 관용어 이해 능력을 살펴본 결과, 일 반 아동은 친숙도에 따라 관용어 이해 정확도에 영향을 받았으나 경도 지적장애 성인은 친숙도에 따른 관용어 이해 능력에 유의한 차이를 보이지 않았다. 저자들은 경도 지적장애 성인의 경우, 인지 능력의 저하가 관용어 추론 및 비유 언어의 의미 유추 능력에 부정 적인 영향을 미쳐서 친숙도가 이해 정확도에 미치는 영향이 미미했 을 것이라고 언급하였다.

관용어 이해와 관련된 선행 연구(Hyun et al., 2011; Mashal \& Kasirer, 2011; Vogindroukas \& Zikopoulou, 2011)는 화용론적 결 함을 갖는 다양한 장애군이 관용어 해석 시 어떤 오류를 보이는지 보고하였다. Hyun 등(2011)은 초등학교 4,5학년 읽기이해부진 아 동, 일반 아동에게 네 가지 보기(정답, 문맥과 관련된 해석의 오답, 문맥과 관련 없는 해석의 오답, 문자적 해석의 오답)가 제시되는 관 용어 이해 과제를 실시하였다. 읽기이해부진 아동은 문자적 해석 오답을 가장 많이 선택하였지만, 일반 아동은 문맥 관련된 해석 오 답을 가장 많이 선택하였다. Mashal과 Kasirer (2011)연구에서도 12-15세의 자폐스펙트럼장애 아동, 학습장애 아동, 일반 아동을 대 상으로 관용어 이해 연구를 진행하였다. 관용어 문항에 네 가지 보 기(정답, 관용적 표현의 문자적 해석의 오답, 문항 관용어의 동사를 반복한 오답, 관련이 없는 해석의 오답)를 제시한 결과, 자폐스펙트 럼장애 아동과 학습장애 아동은 관용어 이해 정확도가 더 낮았으 
며, 일반 아동에 비해 문자적 해석을 더 많이 선택하였다. Vogindroukas와 Zikopoulou (2011)의 연구에서도 고기능 자폐스펙트럼 장애 아동과 아스퍼거증후군 아동이 관용어의 문자적 의미 오류 를 많이 보였다.

이와 같이 최근 관용어 이해 연구가 증가하고 있으나(Ahn, 2006; Han, 2004; Lee \& Park, 2010; Olswang et al., 2007; Shin, 2015), 국 내의 경우 고기능 자폐스펙트럼장애 아동의 관용어 이해에 대한 연구가 의미유형에 한정되어 있어(Lee et al., 2014), 다양한 변수를 포함한 구체적인 관용어 이해 연구가 매우 부족한 실정이다. 그러 나 고기능 자폐스펙트럼장애 아동이 어휘력, 문장 이해 능력이 정 상 범주에 있더라도 화용능력의 결함을 보이고, 화용능력과 관용 어 이해가 관계가 있다는 점을 고려할 때, 대상자의 임상적 특성을 파악할 수 있는 다양한 관용어 연구가 필요하다. 고기능 자폐스펙 트럼장애 아동의 관용어 이해에 영향을 주는 요인을 파악한다면 이들의 언어 중재에 도움이 될 수 있을 것이다. 이에, 본 연구는 학령 기 고기능 자폐스펙트럼장애 아동을 대상으로 좀 더 다양한 변수 를 고려하여 관용어 이해 연구를 진행하고자 하였다.

일반적으로 관용어 이해 연구는 관용어의 의미 유형, 친숙도, 투 명도, 문맥 등을 변인으로 하여 이루어져 왔다. 관용어 의미 유형 중에서 감정표현 관용어와 행위표현 관용어는 학령기 아동이 일상 생활에서 자주 접하는 형태로 사용 빈도가 높고 쉽고 빠르게 발달 되는 경향이 있다는 선행 연구(Chang \& Chang, 1994; Lee, 2004) 에 따라서, 본 연구에서는 관용어의 의미 유형으로 감정표현 관용 어와 행위표현 관용어를 포함시켰다. 또한 고기능 자폐스펙트럼장 애 아동이 감정표현과 관련된 어휘 사용에 어려움이 있다는 보고 가 있기 때문에(Hobson, 1989; Lee et al., 2014; Park \& Lee, 2001), 감정표현과 행위표현 관용어로 의미유형을 분류하여 집단 간 관용 어 이해 능력에 차이가 있는지 살펴보았다. 그리고 본 연구에서는 관용어의 의미유형 외에 친숙도에 초점을 두어 분석하고자 하였다. 이는 자폐스펙트럼장애 아동이 언어 경험이 누적되어도 관용어 사 용을 일반화하는 데 어려움이 있다는 점에 근거하여 어휘론적, 통 사론적 능력에 영향을 받을 수 있는 투명도나 문맥 요소보다 친숙 도에 따른 특성을 파악할 필요가 있다고 판단했기 때문이다. 마지 막으로, 본 연구는 고기능 자폐스펙트럼장애 아동이 관용어를 이 해하지 못할 때 선택하는 오답의 유형이 일반 아동과 차이가 있는 지에 대해서 분석하고자 하였다. 이를 통해서 고기능 자폐스펙트럼 장애 아동이 관용어를 이해할 때 문자적 해석 오류, 관용어 인용 오류 중에서 어떤 오류가 높게 나타나는지 분석하였다.

본 연구의 연구 문제는 다음과 같다.

첫째, 관용어 유형(감정표현 관용어, 행위표현 관용어)에 따른 집
단(고기능 자폐스펙트럼장애 아동, 일반 아동) 간 관용어 이해 정 확도가 유의한차이를 보이는가?

둘째, 관용어 친숙도(고, 저)에 따른 집단(고기능 자폐스펙트럼 장애 아동, 일반 아동) 간 관용어 이해 정확도가 유의한 차이를 보 이는가?

셋째, 각 집단(고기능 자폐스펙트럼장애 아동, 일반 아동) 내에서 오류 유형(문자 해석, 관용어 인용) 간 오답률에 유의한 차이를 보 이는가?

\section{연구방법}

\section{연구대상}

본 연구에서는 생활연령이 7세 1 개월에서 9세 3개월에 해당하는 고기능 자폐스펙트럼장애 아동 $(\mathrm{N}=15)$ 과 일반 아동 $(\mathrm{N}=15)$ 을 대 상으로 하였다. 일반 아동은 (1) K-WISC-IV (Kwak, Oh, \& Kim, 2011)에서 동작성 지능이 70 이상이며, (2) 수용·표현어휘력검사 (REVT; Kim, Hong, Kim, Jang, \& Lee, 2009) 결과에서 수용과 표 현어휘 점수가 - 1 표준편차 이상으로 정상적인 범위에 속하고, (3) 구문의미이해력검사(KOSECT; Pae, Lim, Lee, \& Jang, 2004) 결과 -1 표준편차 이상이며, (4) 부모 및 교사 보고에서 말, 언어 발달 문 제에 과거력이 없는 아동만을 대상으로 선정하였다.

고기능 자폐스펙트럼장애 아동은 (1) 소아정신과 의사에 의해서 DSM-IV의 진단기준에 따라서 자폐성장애(autism disorder)나 전 반적 발달장애(PDD-NOS)로 진단을 받았으며, (2) K-WISC-IV (Kwak et al., 2011)에서 동작성 지능이 70 이상에 해당하고, (3) 수 용·표현어휘력검사(REVT; Kim et al., 2009) 결과에서 수용과 표현 어휘 점수가 -1 표준편차 이상으로 정상적인 범위에 속하며, (4) 구 문의미이해력검사(KOSECT; Pae et al., 2004) 결과 -1 표준편차 이 상이고, (5) 시각과 청각에 문제를 동반하지 않는 경우만을 대상자 로 선정하였다. 두 집단 모두 동작성 지능, 수용 및 표현어휘력, 구문 의미이해력에서 정상 범위에 속하면서 담임교사, 언어치료사, 부모 가 또래와 비교하여 문장 수준에서의 읽기에 어려움을 보이지 않 는다고 보고한 아동만을 선정하였다.

두 집단의 생활연령, 동작성 지능 점수, 수용어휘 점수, 표현어휘 점수, 구문의미이해력 점수에 대한 기술통계 결과는 Table 1에 제시 하였다. 집단 간 동질성 검증을 위해서 일원분산분석(one-way $\mathrm{ANOVA})$ 을 실시한 결과, 생활연령 $\left(F_{(1,28)}=.017, p>.05\right)$, 동작성 지능 점수 $\left(F_{(1,28)}=.241, p>.05\right)$, 수용어휘 점수 $\left(F_{(1,28)}=1.017, p>.05\right)$, 표현 어휘 점수 $\left(F_{(1,28)}=.229, p>.05\right)$, 구문의미이해력 점수 $\left(F_{(1,28)}=.365\right.$, $p>.05)$ 에서 유의한 차이를 보이지 않았다. 
Table 1. Participants' demographic information

\begin{tabular}{lcc}
\hline & HFA group (N=15) & TD group (N=15) \\
\hline Chronological age (yr) & $100.07(7.19)$ & $98.40(6.59)$ \\
K-WISC-IV: performance I0 & $92.47(11.52)$ & $100.40(10.34)$ \\
REVT: receptive & $84.47(7.75)$ & $90.40(8.72)$ \\
REVT: expressive & $86.07(8.15)$ & $92.27(8.09)$ \\
KOSECT & $47.00(4.54)$ & $48.80(4.92)$ \\
\hline
\end{tabular}

Values are presented as mean (SD).

$\mathrm{HFA}=$ children with high-functioning autism spectrum disorder; $\mathrm{TD}=$ children with typical development; K-WISC-IV=Korean-Wechsler Intelligence Scale for Childrenfourth edition (Kwak, Oh, \& Kim, 2011); REVT = Receptive and Expressive Vocabulary Test (Kim, Hong, Kim, Jang, \& Lee, 2009); KOSECT= Korea Sentence Comprehension Test (Pea, Lim, Lee, \& Jang, 2004).

\section{검사도구}

본 연구에서는 관용어 유형과 친숙도에 따른 고기능 자폐스펙트 럼장애 아동의 관용어 이해 능력을 측정하기 위해서 관용어 이해 과제를 개발하였다. 이해 과제는 Jung (2012)의 연구를 통해 고기 능 자폐스펙트럼장애 아동은 읽기 자료로 제시하는 기본조건, 그 림조건, 문맥조건으로 과제를 제시하였을 때 그림조건에서 과제를 이해하는 데 어려움이 큰 것으로 나타났다. 이러한 선행 연구 결과 를 토대로 문맥 단서가 아동의 관용어 이해 과제에 미치는 영향을 최소화하기 위해서, 문맥을 제외시킨 관용어를 읽기로 제시하는 기본조건으로 과제를 개발하였다. 본 과제에 사용될 관용어를 선 정하기 위하여 Kim (2001)의 감정표현 관용어 483개와 Moon (1996) 의 행위표현 관용어 174 개를 관용어 목록으로 구성하였다. 대상자 의 연령을 고려하여 Kim (2003)의 일상생활 영위를 위한 기초어휘 와 Park (2003)의 초등학교 1학년 교과서의 어휘를 참조하여 관용 어 목록에서 적절하지 않은 관용어는 제외하였다. 그리고 초등학 교 저학년의 읽기 발달 수준을 고려하여 관용구의 길이를 2-3어절 로 제한하고, 문장 구조에 있어서도 단문으로 통제하였다.

관용어의 어휘와 문법을 통제한 결과, 관용어 목록에서 감정표 현 관용어 65 개와 행위표현 관용어 30 개가 도출되었다. 도출된 관 용어가 초등학교 저학년 아동에게 적절한지 확인하기 위해서 언어 재활사 3 인에게 5점 평정척도(1점: 매우 적절하지 않음, 2점: 적절하 지 않음, 3점: 보통, 4점: 적절함, 5점: 매우 적절함)로 타당도 검사를 실시한 결과, 평균 4.0 이상의 관용어를 타당하다고 보고 감정표현 관용어 27 개, 행위표현 관용어 24개로 선정하였다. 그리고 선정된 관용어의 친숙도를 구분하기 위해서 초등학교 2 학년 아동 10 명에 게 친숙도 검사를 5점 평정척도(1점: 매우 친숙하지 않음, 2 점: 친숙 하지 않음, 3점: 보통, 4 점: 친숙함, 5 점: 매우 친숙함)를 실시하여, 평 균 4.0 이상의 관용어는 친숙도가 높은 관용어로, 평균 2.0 이하의 관용어는 친숙도가 낮은 관용어로 구분하였다. 이러한 절차를 통
해서 친숙도가 높은 감정표현 관용어 10 개, 친숙도가 낮은 감정표 현 관용어 10 개, 친숙도가 높은 행위표현 관용어 10 개, 친숙도가 낮 은 행위표현 관용어 10 개로 총 40 개의 관용어가 도출되었다.

관용어 이해 과제의 객관식 문항을 개발하기 위해 선행 연구 (Mashal \& Kasirer, 2011; Vogindroukas \& Zikopoulou, 2011)를 참 고하여, 관용어 이해 과제에서 객관식 문항을 정답, 문자 해석의 오 답, 관용어 인용의 오답, 관련 없는 오답 등으로 분류하였다. 본 연 구에서는 고기능 자폐스펙트럼장애 아동은 관용어 이해에서 문자 적 해석의 빈도가 높다고 언급한 선행 연구(Lee et al., 2015; Vogindroukas \& Zikopoulou, 2011)의 결과에 따라서 오답의 유형으로 문자 해석 오류를 선정하였다. 그리고 아동이 관용어 의미 파악을 위해서 같은 글자 단서를 포함하는 문항을 선택하는 경향이 높다 고 보고한 Lee, Kim과 Lee (2007)의 연구 결과를 참조하여 관용어 인용의 오류를 선정하였다. 관용어 이해 과제에서 적절한 오답을 개발하기 위해서, 문자적 해석 오류는 관용어에 포함된 단어의 사 전적 의미로 조합하여 '문자 그대로의 뜻’을 인용하였고, 관용어 인 용 오류는 국립국어연구원의 표준국어대사전에서 같은 단어를 가 진 관용어를 선택하였다. 이 과정에서 정답, 오답(문자 해석, 관용어 인용)에 포함된 어휘가 대상자의 연령에 적절한지를 기초어휘 목록 (Kim, 2003)에서 확인하여 어휘 목록에 포함된 어휘로 수정하였으 며, 문장의 길이를 2-3어절로 제한하였다. 언어재활사 1 급 자격증과 언어병리학 박사학위를 소지한 전문가가 선정된 문자 해석과 관용 어 인용 오답 문장에 대한 타당도를 검증하여 오답을 수정, 보완하 는 단계를 거쳐서 최종적인 오답 보기를 개발하였다. 그리고 문항 의 순서효과를 배제하기 위해서 관용어 유형(감정표현 관용어, 행 위표현 관용어)과 친숙도(고, 저)를 고려하여 문항의 제시 순서를 역균형화(counterbalancing)하고, 보기를 무선화(randomization) 하여 문항의 정답이 1 번 13 개, 2 번 14 개, 3 번 13 개로 배치하였다. 관 용어 이해 과제의 문항과 예시는 Appendixes 1과 2에 제시하였다.

\section{실험절차 및 채점}

본 연구의 관용어 이해 과제는 제 1 연구자가 진행한 후, 검사지를 회수하는 방식으로 실시하였다. 검사 실시 전 연구자는 일반 아동 이 소속된 학급의 담임교사, 고기능 자폐스펙트럼장애 아동의 부 모, 대상 아동에게 검사의 목적, 검사의 구성, 대략적인 검사의 소 요시간, 검사 방법과 유의사항에 대해서 설명한 후에 검사를 실시 하였다. 관용어 이해 과제는 조용하고 독립된 공간(예: 방과 후 교 실, 지역 아동 센터, 언어치료실)에서 아동에게 제공하여 풀도록 하 였다. 대상 아동은 연구자가 나누어준 검사지에 이름, 성별, 생년월 일을 작성하고, 연습문항을 통해서 아동이 검사 절차를 숙지하도 
록 설명하였으며, 검사에 제한 시간을 두지 않고 진행하여 아동이 충분한 시간을 두고 검사에 참여하도록 하였다.

채점은 제 1 연구자가 실시하였으며, 채점방법은 대상자의 응답이 정답과 일치하면 1 점, 일치하지 않으면 0 점으로 채점하였다. 관용어 유형(감정표현 관용어, 행위표현 관용어)에 따른 이해 정확도는 유 형별 문항 수(40개)에서 정확하게 응답한 문항 수의 백분율(\%)로 산출하였으며, 관용어 친숙도(고, 저)에 따른 이해 정확도는 친숙도 별 문항 수(40개)에서 정확하게 응답한 문항 수의 백분율(\%)로 산 출하여, 관용어 이해 정확도가 $0 \%-100 \%$ 가 되도록 하였다. 대상 아 동의 관용어 오류 형태(문자 해석, 관용어 인용)에 따른 오답 비율 은 전체 오류 빈도수에서 오류 형태별 빈도수의 백분율(\%)로 산출 하여, 오답 비율이 $0 \%-100 \%$ 가 되도록 하였다.

\section{신뢰도}

채점은 제 1 연구자가 진행하였으며, 평가자 간 신뢰도(inter-rater reliability)는 제 1 연구자와 평가자 간의 일치도(agreement)로 측정 하였다. 신뢰도 평가자로 언어병리학 석사과정생 1 명이 채점에 참 여하였으며, 채점 전에 평가자에게 문항 답안을 제공하고 채점 방 법에 대해서 설명을 하였다. 전체 자료의 $20 \%$ 인 6 명의 검사지를 무 작위로 추출하여 평가자가 독립적으로 채점하였다. 일치도 측정결 과, $100 \%$ 로 나타났다.

\section{자료의 통계적 처리}

관용어 유형(감정표현 관용어, 행위표현 관용어)에 따른 집단(고 기능 자폐스펙트럼장애 아동, 일반 아동) 간 관용어 이해 정확도에 유의한 차이가 있는지를 살펴보기 위해서 이원혼합분산분석(twoway mixed ANOVA)을 실시하였다. 그리고 관용어 친숙도(고, 저) 에 따른 집단(고기능 자폐스펙트럼장애 아동, 일반 아동) 간 관용 어 이해 정확도에 유의한 차이가 있는지를 살펴보기 위해서 이원혼 합분산분석을 실시하였다. 각 집단 내에서 관용어에 대한 오답 비 율에 유의한 차이를 살펴보기 위해서 대응표본 $t$-검정을 실시하였 다. 연구 문제에 대한 통계분석은 SPSS Windows ver. 18.0 프로그 램(SPSS Inc., Chicago, IL, USA)을 사용하였다.

\section{연구 결과}

\section{관용어 유형에 따른 집단 간 관용어 이해 정확도}

관용어 유형(감정표현 관용어, 행위표현 관용어)에 따른 고기능 자폐스펙트럼장애 아동과 일반 아동의 관용어 이해 정확도에 대한 기술통계 결과는 Table 2에 제시하였다.
관용어 유형에 따른 집단 간 관용어 이해 정확도에 차이가 있는 지 살펴보기 위해서 이원혼합분산분석을 실시하였다(Table 3). 그 결과, 집단에 대한 주효과가 유의하여 $\left(F_{(1,28)}=4.475, p<.05\right)$, 고기 능 자폐스펙트럼장애 아동의 관용어 이해 정확도가 일반 아동에 비해서 유의하게 낮았다. 관용어 유형과 집단의 이차 상호작용 효 과도 유의하게 나타났다 $\left(F_{(1,28)}=13.746, p<.001\right)$. 이는 감정표현 관 용어에서 고기능 자폐스펙트럼장애 아동의 관용어 이해 정확도가

Table 2. Comparison of comprehension accuracy depending on idiom's semantic type and idiom's familiarity between two groups

\begin{tabular}{lll}
\hline & HFA group $(\mathrm{N}=15)$ & TD group $(\mathrm{N}=15)$ \\
\hline Semantic type & & \\
Emotion idiom & $73.00(14.74)$ & $90.67(8.63)$ \\
Action idiom & $79.67(14.20)$ & $78.67(12.74)$ \\
Familiarity & & \\
Familiar idiom & $84.33(12.52)$ & $91.00(7.12)$ \\
Unfamiliar idiom & $69.00(14.66)$ & $78.33(14.96)$ \\
\hline
\end{tabular}

Values are presented as mean (SD).

$H F A=$ children with high-functioning autism spectrum disorder; $T D=$ children with typical development.

Table 3. Two-way mixed ANOVA results of comprehension accuracy depending on idiom's semantic type between two groups

\begin{tabular}{lrrrc}
\hline & SS & df & MS & $F$ \\
\hline Between groups & & & & \\
$\quad$ Group (A) & 41.667 & 1 & 41.667 & $4.475^{*}$ \\
$\quad$ Error & 260.733 & 28 & 9.312 & \\
Within group & & & & \\
$\quad$ Idiom's semantic type (B) & 4.267 & 1 & 4.267 & 1.122 \\
A $\times$ B & 52.267 & 1 & 52.267 & $13.746^{* * *}$ \\
Error & 106.467 & 28 & 3.802 & \\
\hline
\end{tabular}

${ }^{*} p<.05,{ }^{* * *} p<.001$

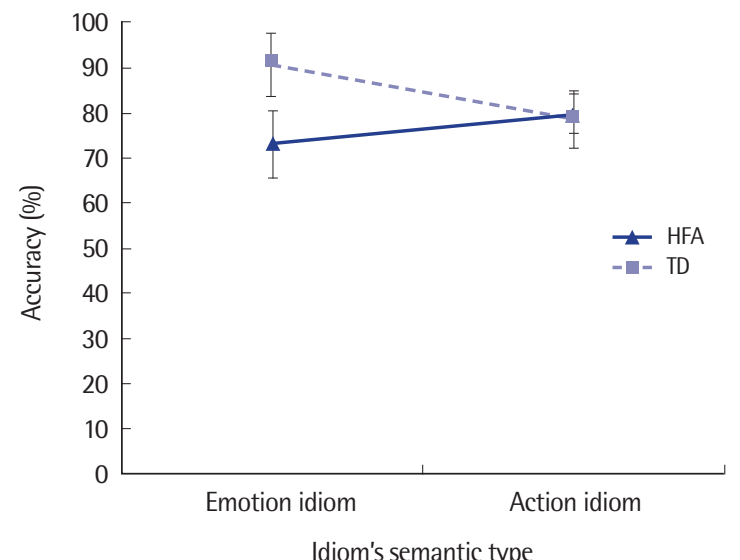

Figure 1. Comprehension accuracy depending on idiom's semantic type between two groups. HFA= children with high-functioning autism spectrum disorders; $\mathrm{TD}=$ children with typical development. 
일반아동에 비해서 유의하게 낮아서 나타난 것이다(Figure 1).

\section{관용어 친숙도에 따른 집단 간 관용어 이해 정확도}

관용어의 친숙도(고, 저)에 따른 고기능 자폐스펙트럼장애 아동 과 일반 아동의 관용어 이해 정확도에 대한 기술통계 결과는 Table 2에 제시하였다.

관용어 친숙도에 따른 집단 간 관용어 이해 정확도에 차이가 있 는지 살펴보기 위해서 이원혼합분산분석을 실시하였다(Table 4). 그 결과, 집단에 대한 주효과가 유의하게 나타나서 $\left(F_{(1,28)}=4.379\right.$, $p<.05)$, 고기능 자폐스펙트럼장애 아동의 관용어 이해 정확도가 일반 아동에 비해서 유의하게 낮았다. 그리고 관용어 친숙도에 대 한 주효과가 유의하여 $\left(F_{(1,28)}=28.305, p<.001\right)$, 두 집단에서 친숙 도가 높은 관용어의 이해 정확도가 친숙도가 낮은 관용어에 비해 서 유의하게 높게 나타났다(Figure 2). 관용어의 친숙도와 집단 간 의 이차 상호작용 효과는 유의하지 않았다.

Table 4. Two-way mixed ANOVA results of comprehension accuracy depending on idiom's familiarity between two groups

\begin{tabular}{lrrrc}
\hline & \multicolumn{1}{c}{ SS } & df & MS & $F$ \\
\hline Between groups & & & & \\
$\quad$ Group (A) & 38.400 & 1 & 38.400 & $4.379^{*}$ \\
$\quad$ Error & 245.533 & 28 & 8.769 & \\
Within group & & & & \\
$\quad$ Idiom's familiarity (B) & 117.600 & 1 & 117.600 & $28.305^{* * *}$ \\
A $\times$ B & 1.067 & 1 & 1.067 & .257 \\
Error & 116.333 & 28 & 4.155 & \\
\hline
\end{tabular}

${ }^{*} p<.05,{ }^{* * *} p<.001$.

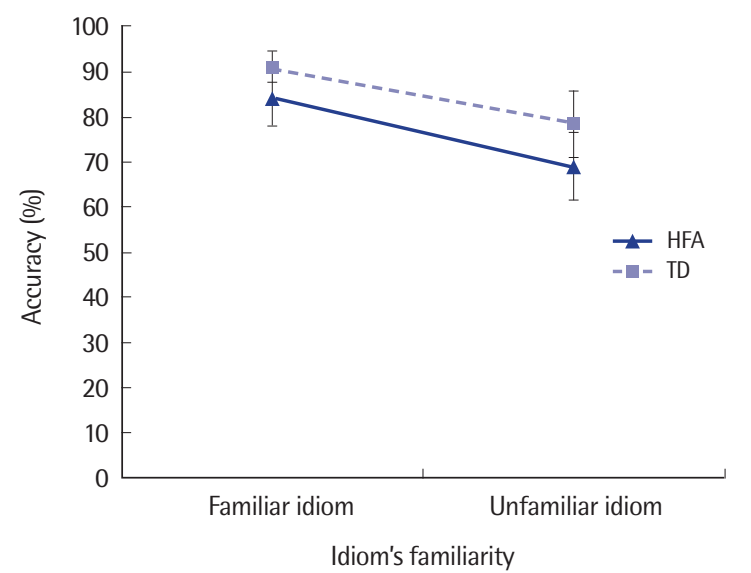

Figure 2. Comprehension accuracy depending on idiom's familiarity between two groups. HFA= children with high-functioning autism spectrum disorders; $\mathrm{TD}=$ children with typical development.

\section{각 집단 내에서의 오류 유형 간 오답률}

고기능 자폐스펙트럼장애 아동과 일반 아동이 관용어를 이해할 때 보이는 오류 형태를 살펴보기 위해서, 오류 형태를 관용어의 문 자 해석 오류와 관용어 인용 오류로 구분하여 살펴보았다. 두 집단 의 관용어 오류 유형에 따른 오답률의 기술통계 결과는 Table 5 에 제시하였다.

고기능 자폐스펙트럼장애 아동의 오류 유형 간 차이를 살펴보기 위해서 대응표본 $t$-검정을 실시한 결과, 문자 해석 오류와 관용어 인용 오류의 오답률에는 유의한 차이를 보이지 않았다 $\left(t_{(1,29)}=.147\right.$, $p>.05)$. 일반 아동의 오류 유형 간 차이를 대응표본 $t$-검정으로 살 펴본 결과, 문자 해석 오류와 관용어 인용 오류의 오답률에 유의한 차이를 보였다 $\left(t_{(1,29)}=-5.931, p<.001\right)$. 즉, 고기능 자폐스펙트럼장 애 아동은 문자 해석과 관용어 인용 오류 유형 간에 오답률에 유의 한 차이를 보이지 않았으나, 일반 아동은 문자 해석 오류의 오답률 이 관용어 인용 오류에 비해서 유의하게 높게 나타났다(Figure 3).

\section{논의 및 결론}

본 연구는 관용어 유형(감정표현 관용어, 행위표현 관용어) 및 친숙도에 따른 고기능 자폐스펙트럼장애 아동과 일반 아동의 관용

Table 5. Incorrect ratio according to error type in each group

\begin{tabular}{lcc}
\hline & HFA group ( $\mathrm{N}=15)$ & TD group $(\mathrm{N}=15)$ \\
\hline Idiom quote & $50.95(25.27)$ & $23.77(25.33)$ \\
Literal interpretation & $49.04(25.27)$ & $81.89(17.86)$ \\
\hline
\end{tabular}

Values are presented as mean (SD).

$H F A=$ children with high-functioning autism spectrum disorder; $T D=$ children with typical development.

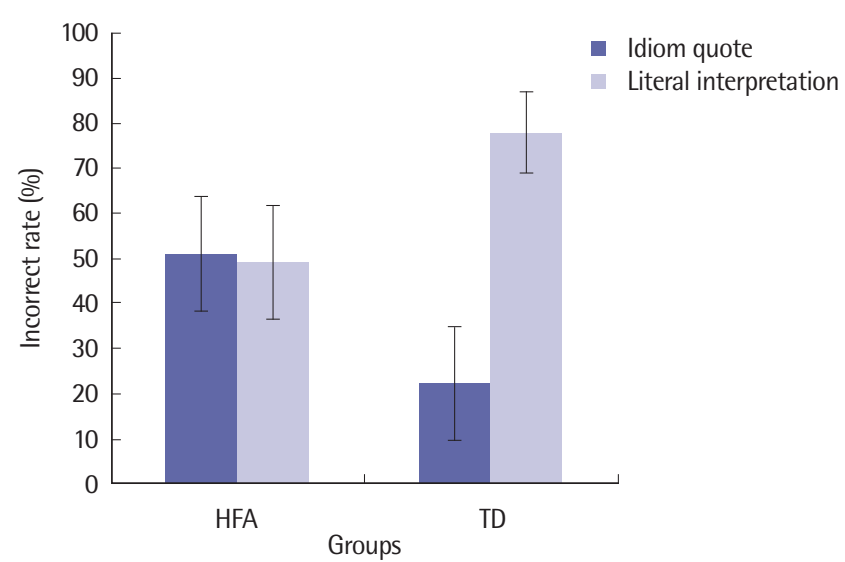

Figure 3. Incorrect ration depending on error type in each group. HFA= children with high-functioning autism spectrum disorders; $T D=$ children with typical development. 
어 이해 정확도에 대해 살펴보고, 각 집단 내에서 나타난 오류 유형 (문자 해석, 관용어 인용)에 어떠한 차이가 있는지 살펴보았다. 연 구 결과, 고기능 자폐스펙트럼장애 아동의 관용어 이해 정확도는 일반 아동에 비해서 유의하게 낮았으며, 특히 고기능 자폐스펙트럼 장애 아동은 일반 아동에 비해서 행위표현 관용어보다는 감정표 현 관용어를 이해하는 데 더 많은 어려움을 보였다. 두 집단 모두에 서 친숙도가 낮은 관용어보다는 친숙도가 높은 관용어의 이해 정 확도가 유의하게 높았다. 일반 아동은 관용어 이해 과제에서 관용 어 인용 오류보다 문자 해석 오류를 유의하게 높은 비율로 보였으 나, 고기능 자폐스펙트럼장애 아동은 문자 해석과 관용어 인용의 두 오류 유형 간에 유의한 차이가 없게 나타나서 더 높은 비율로 사 용하는 관용어 오류 패턴이 없었다.

본 연구에서 고기능 자폐스펙트럼장애 아동은 일반 아동에 비 해 전체적인 관용어 이해 정확도가 유의하게 낮았다. 이는 고기능 자폐스펙트럼장애 아동의 관용어 이해 능력에 대한 선행 연구들의 결과와 일치한다(Lee et al., 2015; Vogindroukas \& Zikopoulou, 2011). 연구자들은 고기능 자폐스펙트럼장애 아동의 관용어 이해 능력이 일반 아동에 비해 낮은 원인이 화용론적 능력의 손상이라 고 언급하였다. Lee 등(2015)은 고기능 자폐스펙트럼장애 아동이 일반 아동에 비해 관용어를 이해하는 능력이 낮다고 보고하면서, 이는 고기능 자폐스펙트럼장애 아동이 화용론적 능력의 결함으로 인해 비유 언어를 해석할 때도 어려움을 보여서 나타난 결과라고 하였다. Vogindroukas와 Zikopoulou (2011)도 고기능 자폐스펙트 럼장애 아동의 관용어 이해 능력의 취약성을 언급하며 이들의 낮 은 추론 능력 및 언어 기술이 관용어 이해 정확도에 영향을 미쳤다 고 강조하였다. 즉, 비유 언어 습득에 중요한 요소인 상황에 대한 민 감성, 추상적 사고 능력의 손상으로, 고기능 자폐스펙트럼장애 아 동의 관용어 이해 정확도가 일반 아동보다 낮았던 것으로 생각된 다. 또한, 고기능 자폐스펙트럼장애 아동은 마음이론에서의 결함 으로 상대방의 의도와 생각을 자연스럽게 추론하는 데에 어려움 을 갖기 때문에, 이러한 특성이 일상생활에 사용되는 다양한 관용 어 습득에도 부정적인 영향을 미쳤을 것이다(Ahn, 2006; Paul et al., 2009).

관용어 유형(감정표현 관용어, 행위표현 관용어)에 따른 관용어 이해 정확도에서도 고기능 자폐스펙트럼장애 아동의 낮은 감정표 현 관용어로 인해 집단 간 이차 상호작용 효과가 유의하게 나타났 다. 이러한 결과는 고기능 자폐스펙트럼장애 아동이 행위에 관련 된 문장보다 감정과 관련된 문장의 의미를 해석할 때 상대방의 의도 를 파악함에 있어 어려움을 보인다는 선행 연구와 일치한다(Dennis, Lazenby, \& Lockyer, 2001; Hobson, 1989; Lee et al., 2014). Lee
등(2014)의 연구에서는 아스퍼거증후군 아동이 행위표현 관용어 에 비해 감정표현 관용어를 더 어려워한다고 보고하며, 그 원인은 아스퍼거증후군 아동이 관용어를 감정에 연결하기보다는 겉으로 나타난 상황이나 단서에 연결시켜 의미를 파악하기 때문이라고 하 였다. 이와 같은 선행 연구에 근거할 때 고기능 자폐스펙트럼장애 아동도 공감 능력, 마음읽기 능력 등의 결함이 있어 행위표현 관용 어에 비해 감정과 관련된 관용어를 더 정확하게 해석하지 못했을 것이다. 그러나 행위표현 관용어에서는 고기능 자폐스펙트럼장애 아동이 일반 아동과 유의한 차이가 나타나지 않았다. 이러한 결과 는 고기능 자폐스펙트럼장애 아동도 무조건 관용어를 이해하지 못 하는 것이 아니라, 일반 아동과 마찬가지로 관용어를 해석할 수 있 는 능력이 있음을 보여준다. 다만, 관용어가 감정표현과 관련된 경 우 고기능 자폐스펙트럼장애 아동이 외연적 행동을 통해 내포적 의미를 파악할 수 있는 능력의 결함으로 감정표현과 관련된 관용어 에서 일반 아동보다 낮은 이해도를 보이는 경향이 있음을 시사한다.

관용어 친숙도(고, 저)에 따른 관용어 이해 정확도는 두 집단 모 두 친숙도가 낮은 관용어보다 친숙도가 높은 관용어에서 유의하게 높았다. Whyte 등(2014)에서도 5-12세의 자폐스펙트럼장애 아동과 언어 연령을 일치시킨 일반 아동을 대상으로 관용어 이해 능력을 살펴본 결과, 두 집단 모두 친숙도가 높은 관용어의 이해 정확도가 친숙도가 낮은 관용어에 비해서 높게 나타났다. 관용어의 친숙도 효과는 고기능 자폐스펙트럼장애뿐 아니라 일반 아동의 관용어 능 력과 관련된 선행 연구(Nippold \& Rudzinski, 1993; Nippold \& Taylor, 2002)에서도 보고된 바 있다. Nippold와 Rudzinski (1993) 는 $11,14,17$ 세 일반 아동을 대상으로 친숙도와 투명도에 따른 관 용어 표현 능력을 검사하였을 때, 친숙도가 낮은 관용어보다 친숙 도가 높은 관용어에서 높은 관용어 능력을 보였다고 하였다. 또한 Nippold와 Taylor (2002)는 11세 아동과 16세 청소년을 대상으로 친숙도와 투명도에 따른 관용어 이해 연구에서 친숙도와 투명도가 높을수록 아동과 청소년 집단 모두 높은 이해도를 보였다고 보고 하였다. 이러한 연구 결과는 고기능 자폐스펙트럼장애 아동도 일반 아동과 동일하게 친숙도가 높은 관용어를 더 쉽게 이해하고 있다 는 것을 의미하며, 고기능 자폐스펙트럼장애 아동의 언어 중재에는 관용어에 대한 친숙도를 고려할 필요가 있다는 것을 시사한다.

집단별로 오류 유형(문자 해석, 관용어 인용)에 따른 오답률을 비 교한 결과, 일반 아동은 문자 해석 오류가 관용어 인용 유형에 비해 유의하게 높은 오답률을 보였으나 고기능 자폐스펙트럼장애 아동 은 오류 유형 간 오답률에 유의한 차이가 없었다. 이와 같은 결과는 고기능 자폐스펙트럼장애의 선행 연구(Jung, 2012; Kaland et al., 2002)와는 다소 차이가 있다. Vogindroukas와 Zikopoulou (2011) 
의 연구에서는 학령기 고기능 자폐스펙트럼장애와 아스퍼거증후 군 아동이 관용어 이해 과제에서 관용어의 문자적 의미 오류를 가 장 많이 선택하였다. Lee 등(2015)의 연구에서도 고기능 자폐스펙 트럼장애 아동은 관용어 이해 과제에서 문자적 해석을 많이 선택 하였고, 고기능 자폐스펙트럼장애 아동의 관용어 이해를 어렵게 하는 요인이 문자적 해석에서의 오류라고 보고하였다. 이와 같이 본 연구가 선행 연구와 다른 결과를 보인 이유는 먼저 검사 방법과 보기 문항의 특성에서 찾아볼 수 있다. 선행 연구에서는 고기능 자 폐스펙트럼장애 아동에게 문맥을 제시하고 관용어 문항을 선택하 도록 하여 이들이 문맥의 도움을 받아 문자 해석 문항을 선택한 반 면, 본 연구에서는 관용어 해석에 도움을 줄 수 있는 문맥 단서 없 이 관용어만 제시함으로써 고기능 자폐스펙트럼장애 아동이 문자 해석을 할 수 있는 기회를 줄였다고 볼 수 있다. 또한, 본 연구에서 관용어 습득이 충분히 이루어지기 전인 저학년 일반 아동이 문자 해석 오류를 더 많이 선택한 것과 달리 고기능 자폐스펙트럼장애 아동은 두 오류 유형에서 유의한 차이를 나타내지 않았는데, 이는 고기능 자폐스펙트럼장애 아동이 어휘의 문자적인 해석이 되지 않 았을 때 의미 분석을 하려는 시도보다는 제시한 관용어에 포함된 글자를 찾아 두 가지 유형의 오류를 임의적으로 선택한 데에서 기 인했을 수 있다. 이와 같은 결과는 Lee 등(2007)의 연구에서 고기능 자폐스펙트럼장애 아동이 관용어에 대한 의미 파악을 위해 문자적 해석이 어려웠을 때 같은 글자 단서를 포함하고 있는 문항을 선택 한 경향을 보인다는 분석과 맥을 같이 한다.

본 연구의 결과는 고기능 자폐스펙트럼장애 아동의 관용어 이해 및 이에 대한 중재에 몇 가지 시사점을 제시한다. 첫째, 고기능 자폐 스펙트럼장애 아동은 화용 능력의 결함으로 관용어 이해에 있어 일반 아동에 비해 전반적으로 어려움이 있다는 것을 밝혔다. 고기 능 자폐스펙트럼장애 아동의 언어 능력을 평가할 때 관용어 이해 를 비공식적 평가에 포함시켜 아동의 언어 특성을 정확히 파악한 다면 언어 중재 목표를 세우는 데 도움이 될 수 있다. 둘째, 고기능 자폐스펙트럼장애 아동의 관용어 이해 능력에는 보존된 유형과 손 상된 유형이 있음을 확인하였다. 이에 따라 고기능 자폐스펙트럼장 애 아동의 언어 중재 시 아동이 제한된 능력을 보이는 관용어 유형 을 중심으로 치료 목표를 설정할 수 있을 것이다. 셋째, 고기능 자폐 스펙트럼장애 아동도 일반 아동처럼 친숙도에 따라 관용어 이해에 서 차이를 보이므로, 언어 중재에서 친숙하지 않은 관용어를 다양 한 상황에서 경험하게 함으로써 친숙도를 높일 필요가 있다. 넷째, 일반 아동은 관용어를 이해하기 위해 문자적 해석을 하려는 노력 을 하는 반면에, 고기능 자폐스펙트럼장애 아동은 문자적 해석의 노력을 보이지 않았다는 연구 결과를 통하여 고기능 자폐스펙트럼
장애 아동에게 다의어나 동음이의어를 제시하여 다양한 층위의 의미를 이해하도록 도움으로써 관용어 구성 요소의 의미를 해석하 고 조합하려는 시도를 할수 있도록 중재에 포함시킬 수 있을 것이다. 본 연구에서는 고기능 자폐스펙트럼장애 아동의 관용어 이해에 대한 본 연구가 초등학교 저학년 아동을 대상으로 진행하였다는 점이 제한점이 될 수 있다. 초등학교 저학년은 추론 능력이 시작되 었지만 완성되지 않은 시점이기 때문에, 향후 연구에서는 연구 대 상의 폭을 초등학교 고학년과 청소년기로 확장할 필요가 있다. 나 아가 초등 학령기 및 청소년기 동안 고기능 자폐스펙트럼장애 아동 의 추론 능력이 발달함에 따라 관용어 유형 및 친숙도에 따른 이해 정확도가 어떠한 변화를 보이는지 연구해야 할 것이다. 또한 본 연 구에서는 관용어 유형을 이분법적으로 분석하였으나, 향후 좀 더 다양한 유형의 관용어로 상세 분류하여 그 이해 정확도를 분석할 필요가 있겠다.

\section{REFERENCES}

Ahn, Y. H. (2006). A study on idiom teaching plan: focusing on Korean of high school (Master's thesis). Kookmin University, Seoul, Korea.

American Psychiatric Association (2000). Diagnostic and statistical manual of mental disorders fourth edition (DSM-IV). Washington, DC: Author.

Chang, S. K., \& Chang, K. H. (1994). A study of Korean idioms. Journal of East Asian Cultures, 25, 295-318.

Dennis, M., Lazenby, A. L., \& Lockyer, L. (2001). Inferential language in highfunction children with autism. Journal of Autism and Developmental Disorders, 31, 47-54.

Gold, R., Faust, M., \& Goldstein, A. (2010). Semantic integration during metaphor comprehension in Asperger syndrome. Brain and Language, 113, 124-134

Han, S. K. (2004). A study on the instruction of idioms under elementary education of Korean language (Master's thesis). Pusan National University, Busan, Korea.

Hobson, R. P. (1989). Beyond cognition: a theory of autism. In G. Dawson (Ed.), Autism: nature, diagnosis, and treatment (pp. 22-48). New York: Guilford Press.

Hyun, H. S., Kim, Y. T., \& Lim, D. (2011). Comparison of idiom comprehension ability of school-aged poor reading comprehenders and typically developing peers: the role of context, transparency and familiarity. Journal of Special Education, 46, 173-195.

Jung, D. H. (2012). The metaphors comprehension of high-functioning autism 
children, Asperger disorder children, normal children by subject types (Master's thesis). Dankook Univeristy, Yongin, Korea.

Kaland, N., Møller-Nielsen, A., Callesen, K., Mortensen, E. L., Gottlieb, D., \& Smith, L. (2002). A new 'advanced' test of theory of mind: evidence from children and adolescents with Asperger syndrome. Journal of Child Psychology and Psychiatry, 43, 517-528.

Kasari, C., Chamberlain, B., \& Bauminger, N. (2001). Social emotions and social relationships: can children with autism compensate? In J. A. Burack, T. Charman, N. Yirmiya, \& P. R. Zelazo, P. R. (Eds.), The development of autism: perspectives from theory and research (pp. 309-323). Mahwah, NJ: Lawrence Erlbaum Associates.

Kim, H. S. (2001). A study on Korean emotional idioms (Doctoral dissertation). Inha University, Incheon, Korea.

Kim, K. (2003). Korean educational vocabularies. Seoul: Pakijung.

Kim, Y. T., Hong, G. H., Kim, K. H., Jang, H. S., \& Lee, J. Y. (2009). Receptive \& expressive vocabulary test (REVT). Seoul: Seoul Community Rehabilitation Center.

Kwak, K. C., Oh, S. W., \& Kim, C. T. (2011). Korean-Wechsler Intelligence Scale for Children-IV (K-WISC-IV). Seoul: Hakjisa.

Lee, D. H., Ko, S. H., \& Hwang, M. A. (2014). Characteristics of idiom's comprehension in school-aged children with Asperger's syndrome. Journal of Speech-Language and Hearing Disorders, 23, 105-112.

Lee, H. R. (2007). Presuppositional skills in children with high functioning autism: given-new information processing and negative sentence comprehension (Doctoral dissertation). Ewha Womans University, Seoul, Korea.

Lee, H. R., Kim, Y. T., \& Lee, S. (2007). Presuppositional skills in children with high functioning autism: given-new information processing. Korean Journal of Communication Disorders, 12, 199-214.

Lee, J. S., \& Park, S. Y. (2010). Influence of familiarity for idioms, gender difference, academic achievement on the abilities of idiom comprehension. Journal of the Korea Contents Association, 10, 466-476.

Lee, K. S. (2004). A study of the teaching method about idioms of Korean language in elementary schools (Master's thesis). Gyeongin National University of Education, Incheon, Korea.

Lee, S. B., Song, S. H., Ham, J. H., Song, D. H., \& Cheon, K. A. (2015). Idiom comprehension deficits in high-functioning autism spectrum disorder using a Korean autism social language task. Yonsei Medical Journal, 56, 16131618.

Lee, Y. S. (1996). A study on idiom in Korean (Master's thesis). Chungbuk National University, Cheongju, Korea.
Levorato, M. C., \& Cacciari, C. (1995). The effects of different tasks on the comprehension and production of idioms in children. Journal of Experimental Child Psychology, 60, 261-283.

Mashal, N., \& Kasirer, A. (2011). Thinking maps enhance metaphoric competence in children with autism and learning disabilities. Research in Developmental Disabilities, 32, 2045-2054.

Moon, K. H. (1996). A study of idiomatic expressions in Korean (Doctoral dissertation). Seoul National University, Seoul, Korea.

Moran, C. A., Nippold, M. A., \& Gillon, G. T. (2006). Working memory and proverb comprehension in adolescents with traumatic brain injury: a preliminary investigation. Brain Injury, 20, 417-423.

Nippold, M. A. (1998). Later language development: the school-age and adolescent years (2nd ed.). Austin, TX: Pro-Ed.

Nippold, M. A., \& Rudzinski, M. (1993). Familiarity and transparency in idiom explanation: a developmental study of children and adolescents. Journal of Speech, Language, and Hearing Research, 36, 728-737.

Nippold, M. A., \& Taylor, C. L. (1995). Idiom understanding in youth: further examination of familiarity and transparency. Journal of Speech, Language, and Hearing Research, 38, 426-433.

Nippold, M. A., \& Taylor, C. L. (2002). Judgments of idiom familiarity and transparency: a comparison of children and adolescents. Journal of Speech, Language, and Hearing Research, 45, 384-391.

Oh, E. S., Hwang, M. A., \& Lim, J. A. (2013). The comprehension of emotional contexts in children with Asperger's disorder. Journal of the Korean Association for Persons with Autism, 13, 1-14.

Oh, J. Y., \& Lee, E. J. (2014). Idiom understanding of adult with mild intellectual disability. Journal of Special Education: Theory and Practice, 15, 417438.

Olswang, L. B., Coggins, T. E., \& Svensson, L. (2007). Assessing social communication in the classroom: observing manner and duration of performance. Topics in Language Disorders, 27, 111-127.

Owens, R. E. (1991). Language development: an introduction (3rd ed.). New York: Macmillan.

Pae, S., Lim, S. S., Lee, J. H., \& Jang, H. S. (2004). Korean Oral Syntax Expression Comprehension Test (KOSECT). Seoul: Seoul Community Rehabilitation Center.

Park, H. O., \& Lee, S. H. (2001). Using words related to psychological-internal states in children with and without autism. Korean Journal of Communication Disorders, 6, 392-405.

Park, S. N. (2003). Study on vocabulary teaching method for elementary school 
student in the lower grades (Master's thesis). Jeonju National University of Education, Jeonju, Korea.

Paul, R., Orlovski, S. M., Marcinko, H. C., \& Volkmar, F. (2009). Conversational behaviors in youth with high-functioning ASD and Asperger syndrome. Journal of Autism and Developmental Disorders, 39, 115-125.

Reed, S. K. (2012). Cognition: theories and applications. Boston, MA: Cengage Learning.

Shin, H. N. (2015). A study of the understanding and related factors of idioms in third and fifth grade students. Journal of Speech-Language \& Hearing Disorders, 24, 135-145.

Taylor, B. A., \& Harris, S. L. (1995). Teaching children with autism to seek information-acquisition of novel information and generalization of respond- ing. Journal of Applied Behavior Analysis, 28, 3-14.

Vogindroukas, I., \& Zikopoulou, O. (2011). Idiom understanding in people with Asperger syndrome/high functioning autism. Revista da Sociedade Brasileira de Fonoaudiologia, 16, 390-395.

Vulchanova, M., Talcott, J. B., Vulchanov, V., Stankova, M., \& Eshuis, H. (2012). Morphology in autism spectrum disorders: local processing bias and language. Cognitive Neuropsychology, 29, 584-600.

Whyte, E. M., Nelson, K. E., \& Scherf, K. S. (2014). Idiom, syntax, and advanced theory of mind abilities in children with autism spectrum disorders. Journal of Speech, Language, and Hearing Research, 57, 120-130.

Wing, L. (1981). Asperger's syndrome: a clinical account. Psychological Medicine, 11, 115-129. 
Appendix 1. Idiom comprehension task

\begin{tabular}{|c|c|c|c|c|}
\hline & Idiom & Correct answer & $\begin{array}{c}\text { Incorrect answer } \\
\text { (literal interpretation) }\end{array}$ & $\begin{array}{c}\text { Incorrect answer } \\
\text { (idiom quote) }\end{array}$ \\
\hline \multicolumn{5}{|c|}{ Emotion-Familiar idiom comprehension task } \\
\hline 1 & 가슴이 뛰다. & 마음이 조마조마하다. & 심장이 뛰다. & 가슴이 뜨겁다. \\
\hline 2 & 눈앞이 캄캄하다. & 너무 막막하다. & 방이 어둡다. & 하늘이 캄캄하다. \\
\hline 3 & 땅을 치다. & 슬프고 분하다. & 땅을 망치로 치다. & 땅에 떨어지다. \\
\hline 4 & 밥맛이 떨어지다. & 하는 행동이 실다. & 밥이 떨어지다. & 먹고 떨어지다. \\
\hline 5 & 배가 아프다. & 심술이 나다. & 배탈이 나다. & 배를 내밀다. \\
\hline 6 & 빛이 보이다. & 희망이 생기다. & 불빛이 보이다. & 빛이 나다. \\
\hline 7 & 속이 시원하다. & 마음이 후련하다. & 몸에 바람이 들어가다. & 속이 보이다. \\
\hline 8 & 속이 타다. & 걱정되고 불안하다. & 살이 타다. & 속이 풀리다. \\
\hline 9 & 속이 터지다. & 매우 답답하다. & 살이 찢어지다. & 속을 뽑다. \\
\hline 10 & 토끼 눈이 되다. & 매우 놀라다. & 눈이 크다. & 눈을 맞추다. \\
\hline \multicolumn{5}{|c|}{ Emotion-Unfamiliar idiom comprehension task } \\
\hline 11 & 가슴을 찌르다. & 마음이 아프다. & 칼로 가슴을 찌르다. & 가슴에 새기다. \\
\hline 12 & 가슴을 펴다. & 매우 당당하다. & 몸을 웅크렸다가 펴다. & 허리를 펴다. \\
\hline 13 & 눈길을 모으다. & 함께 집중하다. & 눈을 마주보다. & 눈길을 거두다. \\
\hline 14 & 눈에 남다. & 계속 생각이 난다. & 눈에 먼지가 있다. & 눈에 띄다. \\
\hline 15 & 눈에 들다. & 좋아하다. & 눈에 먼지가 들어가다. & 눈이 나오다. \\
\hline 16 & 눈에 차다. & 마음에 들다. & 발로 눈을 차다. & 눈이 맞다. \\
\hline 17 & 둘도 없다. & 오직 너뿐이다. & 둘만 있다. & 개뿔도 없다. \\
\hline 18 & 발걸음이 가볍다. & 마음이 홀가분하다. & 신발이 가볍다. & 주머니가 가볍다. \\
\hline 19 & 손에 땀이 나다. & 매우 긴장하다. & 더워서 손에 땀나다. & 땀을 빼다. \\
\hline 20 & 얼굴을 돌리다. & 모른 척 하다. & 고개를 돌리다. & 얼굴을 들다. \\
\hline \multicolumn{5}{|c|}{ Action-Familiar idiom comprehension task } \\
\hline 21 & 꼬리를 치다. & 유혹하다. & 손으로 꼬리를 때리다. & 꼬리가 길다. \\
\hline 22 & 눈을 감다. & 사람이 죽다. & 눈을 꼭 감다. & 눈을 붙이다. \\
\hline 23 & 발이 넓다. & 아는 사람이 많다. & 발이 크다. & 발이 빠르다. \\
\hline 24 & 두 손을 들다. & 포기하고 그만두다. & 손을 위로 들다. & 머리를 들다. \\
\hline 25 & 뒤를 밟다. & 몰래 쫓아간다. & 그림자를 밟다. & 뒤를 밀다. \\
\hline 26 & 입이 무겁다. & 비밀을 잘 지킨다. & 입이 크다. & 입을 막다. \\
\hline 27 & 입이 짧다. & 음식을 적게 먹는다. & 입이 작다. & 입을 다물다. \\
\hline 28 & 입을 씻다. & 모른 척 하다. & 양치질을 하다. & 입만 살다. \\
\hline 29 & 한 눈을 팔다. & 집중을 못하다. & 한쪽 눈을 팔다. & 한 눈 붙이다. \\
\hline 30 & 한 배를 타다. & 함께 하다. & 같이 배를 타다. & 줄을 타다. \\
\hline \multicolumn{5}{|c|}{ Action-Unfamiliar idiom comprehension task } \\
\hline 31 & 다리를 놓다. & 소개를 시켜주다. & 강에 다리를 세우다. & 다리를 건너다. \\
\hline 32 & 뒤를 보다. & 대변을 보다. & 뒤를 돌아보다. & 뒤를 노리다. \\
\hline 33 & 목에 힘을 주다. & 다른 사람을 무시하다. & 목이 아프다. & 목이 막히다. \\
\hline 34 & 손을 내밀다. & 도와달라고 하다. & 손을 앞으로 뻗다. & 손을 빼다. \\
\hline 35 & 손을 놓다. & 하던 일을 멈추다. & 손을 잡았다가 놓다. & 손을 거치다. \\
\hline 36 & 손을 보다. & 때려주다. & 손을 쳐다보다. & 손이 놀다. \\
\hline 37 & 손을 씻다. & 일을 그만두다. & 손을 비누로 씻다. & 손이 맵다. \\
\hline 38 & 손을 잡다. & 함께 일을 하다. & 악수를 하다. & 손을 내밀다. \\
\hline 39 & 입을 모으다. & 함께 말을 하다. & 입을 동그랗게 내밀다. & 입을 맞추다. \\
\hline 40 & 피땀을 흘리다. & 열심히 노력하다. & 피와 땀이 나다. & 한 귀로 흘리다. \\
\hline
\end{tabular}


Appendix 2. Examples of idiom comprehension tasks

\begin{tabular}{|c|c|}
\hline $\begin{array}{l}\text { 연습 문제 } \\
\text { 1. 열을 받다'란 무슨 뜻일까요? }\end{array}$ & $\begin{array}{l}\text { 연습 문제 } \\
\text { 2. '입이 가볍다'란 무슨 뜻일까요? }\end{array}$ \\
\hline (1) 너무 흥분하다. & (1) 입이 작다. \\
\hline (2) 열을 받아서 뜨겁다. & (2) 함부로 말을 하다. \\
\hline (3) 열을 올리다. & (3) 입만 살다. \\
\hline 본문항 & 본 문항 \\
\hline 1. '토끼 눈이 되다'란 무슨 뜻일까요? & 2. '발걸음이 가볍다'란 무슨 뜻일까요? \\
\hline (1) 매우 놀라다. & (1) 주머니가 가볍다. \\
\hline (2) 눈이 크다. & (2) 마음이 홀가분하다. \\
\hline (3) 눈을 맞추다. & (3) 신발이 가볍다. \\
\hline 3. '한 배를 타다'란 무슨 뜻일까요? & 4. '피땀을 흘리다'란 무슨 뜻일까요? \\
\hline (1) 함께 하다. & (1) 피와 땀이 나다. \\
\hline (2) 같이 배를 타다. & (2) 한 귀로 흘리다. \\
\hline (3) 줄을 타다. & (3) 열심히 노력하다. \\
\hline 5. '배가 아프다'란 무슨 뜻일까요? & 6. '손에 땀이 나다'란 무슨 뜻일까요? \\
\hline (1) 배를 내밀다. & (1) 더워서 손에 땀나다. \\
\hline (2) 배탈이 나다. & (2) 매우 긴장하다. \\
\hline (3) 심술이 나다. & (3) 땀을 빼다. \\
\hline 7. '두 손을 들다’란 무슨 뜻일까요? & 8. ‘다리를 놓다'란 무슨 뜻일까요? \\
\hline (1) 포기하고 그만두다. & (1) 소개를 시켜주다. \\
\hline (2) 머리를 들다. & (2) 강에 다리를 세우다. \\
\hline (3) 손을 위로 들다. & (3) 다리를 건너다. \\
\hline 9. ‘빛이 보이다’란 무슨 뜻일까요? & 10. '가슴을 찌르다'란 무슨 뜻일까요? \\
\hline (1) 불빛이 보이다. & (1) 마음이 아프다. \\
\hline (2) 빛이 나다. & (2) 가슴에 새기다. \\
\hline (3) 희망이 생기다. & (3) 칼로 가슴을 찌르다. \\
\hline
\end{tabular}




\title{
국문초록
}

\author{
관용어 의미 유형과 친숙도에 따른 학령기 고기능 자폐스펙트럼장애 아동의 관용어 이해 능력 \\ 이송이 ${ }^{*} \cdot$ 배희숙 ${ }^{2} \cdot$ 이영미 $^{3}$ \\ 1 우송대학교 보건복지대학원 언어치료· 청각재활학과, ${ }^{2}$ 우송대학교 언어치료 - 청각재활학과, ${ }^{3}$ 동명대학교 언어치료학과
}

배경 및 목적: 본 연구에서는 관용어 유형(감정표현, 행위표현)과 친숙도(고, 저)에 따른 학령기 고기능 자폐스펙트럼장애 아동과 일반 아동 간의 관용어 이해 정확도에 유의한 차이가 있는지 살펴보고, 집단 내에서 오류 유형에 따른 오답률에 유의한 차이가 있는지 살펴 보고자 하였다. 방법: 동작성 지능과 언어발달이 정상 범위에 있는 학령기 고기능 자폐스펙트럼장애 아동 $(\mathrm{N}=15)$ 과 생활연령을 일치 시킨 일반 아동 $(\mathrm{N}=15)$ 을 대상으로 하였다. 관용어 유형과 친숙도를 고려하여 개발한 관용어 이해 과제를 대상 아동에게 실시하여, 관 용어 유형과 친숙도에 따른 이해 정확도를 측정하고 오류 유형에 따른 오답률을 산출하였다. 결과: 고기능 자폐스펙트럼장애 아동의 관용어 이해 정확도는 일반 아동에 비해서 유의하게 낮았으며, 고기능 자폐스펙트럼장애 아동은 행위표현에 비해서 감정표현에서 관 용어 이해 정확도가 유의하게 낮았다. 두 집단 모두 친숙도가 높은 관용어의 이해 정확도가 친숙도가 낮은 관용어보다 유의하게 높았 다. 오답 유형 분석 결과, 고기능 자폐스펙트럼장애 아동은 오답 유형 간에 유의한 차이가 없었다. 논의 및 결론: 고기능 자폐스펙트럼 장애 아동의 관용어 이해 능력은 일반 아동에 비해서 낮았으며, 감정표현 관용어와 친숙도가 낮은 관용어의 이해 능력이 일반 아동에 비해 취약한 것으로 나타났다. 이는 고기능 자폐스펙트럼장애 아동의 관용어 이해 능력 향상을 위해서 관용어 유형과 친숙도를 고려한 중재가 필요함을 시사한다.

핵심어: 고기능 자폐스펙트럼장애, 학령기 아동, 관용어, 의미유형, 친숙도

본 연구는 제1저자의 석사학위논문을 수정·보완하였음.

\section{참고문헌}

곽금주, 오상우, 김청택(2011). 웩슬러 아동용지능검사(K-WISC-IV). 서울: 학지사.

김광해(2003). 등급별 국어교육용 어휘. 서울: 박이정.

김영태, 홍경훈, 김경희, 장혜성, 이주연(2009). 수용·표현어휘력검사(REVT). 서울: 서울장애인종합복지관.

김향숙(2001). 한국어 감정표현 관용어 연구. 인하대학교대학원 박사학위논문.

문금현(1996). 국어의 관용 표현 연구. 서울대학교대학원 박사학위논문.

박선남(2003). 초등학교 저학년 어휘 지도 방법 연구. 전주교육대학교대학원 석사학위논문.

박현옥, 이소현(2001). 자폐아동과 일반아동의 심리적 상태에 대한 표현어휘 능력 비교. 언어청각장애연구, 6, 392-405.

배소영, 임선숙, 이지희, 장혜성(2004). 구문의미이해력검사. 서울: 서울장애인종합복지관.

신후남(2015). 초등학교 3, 5학년의 관용어 이해 및 관련요인에 대한 연구. 언어치료연구, 24, 135-145.

안연희(2006). 국어 관용어 지도 방안 연구: 고등학교 국어를 중심으로. 국민대학교대학원 석사학위논문.

오은실, 황민아, 임종아(2013). 아스퍼거 아동의 정서적 맥락 이해 결함. 자폐성장애연구, 13, 1-14.

오진영, 이은주(2014). 경도 지적 장애 성인의 관용어 이해 능력. 특수교육 저널: 이론과 실천, 15, 417-438.

이광순(2004). 초등 국어교육에서의 관용표현 지도 방안 연구. 경인교육대학교대학원 석사학위논문.

이다희, 고선희, 황민아(2014). 학령기 아스퍼거 아동의 관용어 이해 특성. 언어치료연구, 23, 105-112.

이연숙(1996). 국어 관용어 연구. 충북대학교대학원 석사학위논문.

이진숙, 박소영(2010). 관용어의 친숙도, 성별, 학업성취도가 관용어 이해하기 능력에 미치는 영향. 한국콘텐츠학회, 10, 466-476.

이희란(2007). 고기능 자폐아동의 전제능력: 새로운 정보의 처리와 부정문 이해 과정을 중심으로. 이화여자대학교대학원 박사학위논문. 
이희란, 김영태, 이승복(2007). 고기능 자폐아동의 주어진 정보와 새로운 정보 처리능력. 언어청각장애연구, 12, 199-214.

장세경, 장경희(1994). 국어 관용어에 관한 연구: 정서표현을 중심으로. 동아시아문화연구, 25, 295-318.

정다히(2012). 과제유형에 따른 고기능 자폐성 장애아동, 아스퍼거 장애아동, 일반아동의 은유이해 비교. 단국대학교대학원 석사학위논문. 한세경(2004). 초등학교 국어과 관용어 지도 연구. 부산교육대학교대학원 석사학위논문.

현혜숙, 김영태, 임동선(2011). 읽기이해부진 아동의 관용어 유형 및 과제제시 방법에 따른 관용어 이해 능력. 특수교육학연구, 46, 173-195. 